\title{
UMA ABORDAGEM DA FORMAÇÃO INICIAL DOCEN- TE EM AMBIENTE VIRTUAL DE APRENDIZAGEM
}

\author{
Janayna Bertollo Cozer Casotti \\ (Universidade Federal do Espírito Santo) \\ https://orcid.org/0000-0001-7459-4268 \\ Daísa Teixeira \\ (Universidade Federal do Espírito Santo) \\ https://orcid.org/0000-0001-9934-4791
}

\section{RESUMO}

Neste artigo, pretende-se verificar como participantes de um curso de formação inicial docente, nas práticas de interação em ambiente virtual de aprendizagem (AVA), vão refletir sobre sua própria experiência de aprendizagem. Para tanto, o aporte teórico em que se busca respaldar a análise é a Teoria Semiolinguística do Discurso, de Charaudeau $(2005,2008)$, considerando-se, sobretudo, a concepção de ato de linguagem como uma interação de intencionalidades. Os dados para análise foram gerados a partir de um fórum de apresentação, no escopo da disciplina Linguagem I, oferecida no ano de 2015, pela Plataforma Moodle, para alunos em formação inicial docente. $\mathrm{O}$ objetivo desse fórum era que os participantes se apresentassem e fizessem comentários acerca de seu processo de alfabetização. Assim, busca-se verificar quais comportamentos enunciativos esses alunos (em formação inicial docente) apresentam na mise en scène do ato comunicativo de que eles participam em contexto digital. Os resultados desse trabalho de análise permitem reconhecer a posição que o sujeito ocupa em relação ao interlocutor, em relação ao que ele mesmo diz e também em relação ao que o outro diz.

PALAVRAS-CHAVE: Formação docente; interação em AVA; comportamentos enunciativos. 


\section{AN APPROACH TO INITIAL TEACHER EDUCATION IN A VIRTUAL LEARNING ENVIRONMENT}

\section{ABSTRACT}

In this article, we intend to verify how participants of an initial teacher education. course, in the interaction practices in a virtual learning environment (VLE), will reflect on their own learning experience. To that end, the theoretical contribution sought to support the analysis is the Discourse Semiolinguistic Theory, by Charaudeau (2005, 2008), considering, above all, the concept of language act as an interaction of intentionalities. The data for analysis were generated from a presentation forum, within the scope of the discipline Linguagem I, offered in the year 2015, by the Moodle Platform, for students in initial teacher education. The purpose of this forum was for participants to introduce themselves and comment on their literacy process. Thus, it is sought to verify which enunciative behaviors these students (in initial teacher education) present in the mise en scène of the communicative act of which they participate in digital context. The results of this work of analysis allow us to recognize the position that the subject occupies in relation to the interlocutor, in relation to what he himself says and also in relation to what the other says.

KEYWORDS: Teacher education; interaction in AVA; enunciative behaviors.

\section{Introdução ${ }^{1}$}

A inserção das tecnologias da informação e comunicação (TICs) em contextos educacionais tem gerado inúmeras discussões tanto na sociedade em geral quanto na academia. Em todas essas discussões, o que se tem reconhecido é que qualquer trabalho nessa direção implica mudança na maneira como se concebe o processo de ensino e aprendizagem. $\mathrm{Na}$ contemporaneidade, a cultura digital, intensamente perpassada por múl-

1 Este artigo é resultado de produção colaborativa entre a primeira autora, que recebeu apoio da Capes entre 2015 e 2016, quando realizou pós-doutorado na Universidade Aberta, em Lisboa, Portugal, e a segunda autora. 
tiplas linguagens, requer uma mudança frente ao modo como se concebe a aprendizagem, o que significa uma ruptura com uma concepção tradicional de aula, em que o professor, em uma sequência metódica, expõe determinado conteúdo, orienta algumas atividades, corrige essas tarefas e, depois, aplica uma avaliação para verificar a aprendizagem dos alunos. Hoje há que se pensar uma nova arquitetura pedagógica que dê conta dos desafios de uma geração digital.

De fato, uma aula que coloca em primeiro plano o conhecimento que deve ser transmitido ao aluno negligencia os inúmeros recursos que podem auxiliar tanto o professor na dinamização de sua prática pedagógica, quanto o educando na produção do conhecimento. Segundo Rangel (2005), o conhecimento construído pelas ciências da aprendizagem sobre $o$ que é aprender nos leva a questionar concepções e práticas estabelecidas:

Por que não fazer das situações de ensino um momento de interação planejada, se já sabemos que é preciso interagir com o objeto de conhecimento e outros parceiros, para aprender? Por que ignorar as crenças e as hipóteses do aprendiz, se é com base nelas que o sujeito elabora o conhecimento novo? Por que não levar as práticas de ensino a tirarem parte significativa de sua força e eficácia dos movimentos do próprio aprendiz em seu previsível esforço por aprender? Por que insistir em práticas de ensino que, por mais bem intencionadas que sejam, andam na contramão da aprendizagem? (RANGEL, 2005, p. 15).

É, portanto, neste sentido - o de buscar reconhecer, nas práticas de letramento digital, uma possibilidade de percepção do desafio e da reflexão do indivíduo na construção do conhecimento - que nos propusemos a investigar interações entre alunos de um curso de formação inicial docente a distância.

Há um tempo, essas interações estabelecidas por meio de ambientes virtuais de aprendizagem (AVA) vêm-se tornando importante objeto de investigação, uma vez que permitem perceber as potencialidades que as novas tecnologias oferecem ao processo de ensino e aprendizagem, compreendido como coconstrução de saberes. O número cada vez mais crescente de usuários na rede mundial de computadores e também a quantidade de cursos na modalidade a distância ou de cursos que utilizam as novas tecnologias em aulas presenciais indicam a necessidade de se repensar práticas já cristalizadas. As novas tecnologias requerem uma reorganização do espaço escolar, agora fundamentado na interação, no trabalho colaborativo e no protagonismo dos alunos que, na e pela 
linguagem, vão exercer influência sobre o outro e também desse outro receberão influência.

Nesse sentido, Amaral e Amaral (2008, p. 18) defendem que, em ambiente virtual de aprendizagem, a linguagem precisa estimular a interação. Trata-se, pois, de um espaço que possibilita não só "novas formas de acesso à informação, mas também novos processos cognitivos, novas formas de conhecimento, novas maneiras de ler e escrever, enfim, um novo espaço de letramento". E é exatamente isso que objetivamos verificar aqui.

O trabalho aqui apresentado integra uma pesquisa mais ampla de pós-doutorado, intitulada Comportamentos enunciativos de professores da educação básica em interações em ambiente virtual de aprendizagem, empreendida com o objetivo de propor uma reflexão em torno de práticas de letramento digital na formação de estudantes no Brasil e em Portugal, a fim de contribuir para a reflexão em torno da inserção da cultura das novas tecnologias na prática pedagógica.

O presente trabalho tem como objetivo apresentar os resultados do acompanhamento de um curso a distância no Brasil e organiza-se, portanto, da seguinte maneira: primeiramente, abordamos o aporte teórico de nossa investigação, a Teoria Semiolinguística do Discurso, de Patrick Charaudeau (2001, 2008); em seguida, discorremos sobre a metodologia da pesquisa qualitativa realizada; e, por fim, apresentamos a análise de dados gerados na plataforma moodle da Universidade Federal do Espírito Santo.

\section{A interação pela linguagem}

Charaudeau (2001) concebe o ato de linguagem como uma interação de intencionalidades, que apresenta uma dada expectativa de significação e que, por isso, se liga a certo número de ritos sociolinguageiros, já que se constitui em "produto da ação de seres psicossociais que são testemunhas mais ou menos conscientes das práticas sociais e das representações imaginárias da comunidade a qual pertencem" (CHARAUDEAU, 2001, p. 29).

Para explicar essa interação entre os sujeitos que compõem o quadro comunicativo, o teórico francês apresenta a noção de contrato de comunicação. Todo ato linguageiro, segundo Charaudeau (2001), realiza-se dentro de um tipo específico de relação contratual, que é implicitamente reconhecido pelos sujeitos e que define aspectos ligados ao plano comunicacional, psicossocial e intencional. Os atos de linguagem produzidos 
em ambientes virtuais de aprendizagem não fogem a isso.

Tal relação contratual depende de componentes de três tipos: o comunicacional, relativo ao quadro físico da situação interacional; o psicossocial, relativo aos estatutos que os parceiros reconhecem um no outro; e o intencional, relativo ao conhecimento que cada um dos parceiros possui ou constrói, de forma imaginária, sobre o outro. (Cf. CHARAUDEAU, 2001, p. 31). Pressupõe-se, como na terminologia jurídica (já que a ideia foi-lhe tomada de empréstimo), a existência de um acordo entre as partes, em torno de um compromisso comum, de modo que o sucesso do ato de linguagem condiciona-se à observância de determinadas regras implícitas.

Os atos de linguagem resultam, pois, de regras implícitas estabelecidas socialmente e partilhadas pelos interlocutores. Tais normas formam um conjunto de limitações que restringem as condições de produção e interpretação da linguagem. De acordo com Charaudeau (2005, p. 1718), "a estruturação de um ato de linguagem comporta dois espaços: um espaço de restrições, que compreende as condições mínimas às quais é necessário atender para que o ato de linguagem seja válido, e um espaço de estratégias, que corresponde às escolhas possíveis à disposição dos sujeitos na mise-en-scène do ato de linguagem".

Nesse modelo de compreensão do processo enunciativo, o ato de linguagem corresponde a uma mise en scène da significação. A esse respeito, vale lembrar o exemplo de Machado (2001), quando trata do lado teatral da encenação necessária a que tenhamos sucesso em nossas interações linguageiras. Segundo a autora, um professor $\mathrm{X}$

não vai falar do mesmo modo que fala em uma situação de trabalho, diante de seu médico: no consultório deste, expondo um problema de saúde, sua mise en scène linguageira - e seu papel de sujeito comunicante - vão mudar em relação ao papel que X adota em suas aulas. Saindo do consultório médico, $\mathrm{X}$ encontra um velho amigo da época em que ele morava no interior de São Paulo: uma nova mudança na mise en scène comunicativa de $\mathrm{X}$ se impõe. É óbvio que se $\mathrm{X}$ guardasse sempre a mesma mise en scène usada em seu trabalho, na sala de aula, não conseguiria se comunicar bem nem com seu médico nem com seu velho amigo: no máximo, passaria por uma pessoa aborrecida, enfatuada. (MACHADO, 2001, p. 50-51)

Dessa mise en scène participam os parceiros da interação, de cujos saberes compartilhados dependem a produção e a interpretação. Levando em conta que não é possível compreender a linguagem desprovida de sua 
dimensão situacional, entendemos ser importante definir esses sujeitos que participam das trocas linguageiras no jogo da comunicação. A nosso ver, um dos pontos fortes da Semiolinguística é o fato de ela considerar o ato de linguagem como uma espécie de jogo, em que se tem a expectativa de ganhar. Em todo ato de linguagem, estaria implícita uma aposta, um desafio lançado ao outro.

Desse jogo participam quatro sujeitos comunicacionais, que se articulam em dois circuitos de produção: o externo e o interno. No circuito externo, encontram-se os parceiros, interlocutores, que agem como seres sociais, possuidores de intenções - o sujeito comunicante (EUc) e o sujeito interpretante (TUi). No circuito interno, situam-se os protagonistas - chamados de intralocutores - o sujeito enunciador (EUe) e o sujeito destinatário (TUd), sujeitos de fala, responsáveis pelo ato de enunciação. Enquanto o sujeito comunicante (EUc) é responsável pela produção, a interpretação compete ao sujeito interpretante (TUi), que pode constituir-se em coautor, na medida em que, ao interpretar a enunciação, acrescenta implícitos não pensados pelo sujeito comunicante.

Todavia, para fazer o contrato comunicacional funcionar, é preciso que o sujeito comunicante (EUc) e o interpretante (TUi) se abram à inclusão de outros sujeitos na cena enunciativa: os protagonistas do ato de comunicação, quais sejam, o sujeito enunciador (EUe) e o sujeito destinatário (TUd). Assim, o sujeito comunicante aciona um sujeito enunciador (EUe) que se dirige, em primeira instância, a um TUd (sujeito destinatário também idealizado). Portanto, o sujeito comunicante constrói, de acordo com a sua finalidade de comunicação, uma imagem do sujeito enunciador e, além disso, imagina um leitor ideal a quem se dirige, a fim de que possa alcançar seus objetivos. Da mesma forma, no processo de interpretação, o sujeito interpretante, a partir da imagem que constrói do sujeito enunciador, formula hipóteses sobre o sujeito comunicante.

Interessa-nos, aqui, sobremaneira, perceber de que maneira os protagonistas - e não apenas os seres sociais, com existência real - agem na mise en scène de um ato de comunicação que se dá em ambiente virtual de aprendizagem. Assim, pretendemos enfocar o modo de organização enunciativo do discurso, uma vez que permite reconhecer a posição do locutor em relação ao interlocutor, em relação ao dito e também em relação a outros discursos.

Procuraremos, pois, verificar como professores em formação inicial revelam suas posições discursivas na interação em ambientes virtuais 
de aprendizagem. Acreditamos que, na medida em que, como aluno, realiza experiências práticas de uso das tecnologias, vai também refletir sobre as ações de linguagem que realiza, pensando sobre sua própria experiência de aprendizagem e também sobre formas de utilizar as tecnologias.

\section{A organização enunciativa do discurso}

Partindo do conceito fundamental na Teoria Semiolinguística do Discurso, podemos dizer que a concepção de ato de linguagem de Charaudeau (2008) vai além da concepção formalista de linguagem como forma de comunicação que se estabelece entre emissor e receptor, por intermédio de uma mensagem. Para Charaudeau (2008, p.44), o ato de linguagem corresponde a um encontro dialético entre o processo de produção e o processo de interpretação, que envolvem os protagonistas da linguagem: o sujeito produtor do ato de linguagem (EU) e o sujeito interlocutor desse mesmo ato (TU).

Assim, não podemos pensar em um TU apenas como receptor. Para além disso, esse sujeito vai construir uma interpretação, considerando seu ponto de vista em relação às circunstâncias do discurso e também em relação às intenções do sujeito produtor. $\mathrm{O}$ ato de linguagem constitui-se, portanto, como uma interação de intencionalidades, que apresenta uma dada expectativa de significação e que, por isso, liga-se a um certo número de ritos sociolinguageiros, já que se constitui em "produto da ação de seres psicossociais que são testemunhas mais ou menos conscientes das práticas sociais e das representações imaginárias da comunidade a qual pertencem". (Charaudeau, 2001, p. 29). Nesse modelo de compreensão do processo enunciativo, o ato de linguagem corresponde, pois, a uma mise en scène da significação, necessária a que tenhamos sucesso em nossas interações linguageiras.

Com vistas a apreender como os protagonistas agem na mise en scène do ato de linguagem, precisamos nos deter no modo de organização enunciativo, que marca a posição do locutor em relação ao interlocutor, em relação ao dito e também em relação a outros discursos. De acordo com Charaudeau (2008, p. 82), são funções do modo enunciativo: "Estabelecer uma relação de influência entre locutor e interlocutor num comportamento ALOCUTIVO; revelar o ponto de vista do locutor, num comportamento ELOCUTIVO; retomar a fala de um terceiro, num comportamento DELOCUTIVO”.

No comportamento alocutivo, o locutor enuncia sua posição em re- 
lação ao interlocutor, a partir do momento em que age sobre ele (ponto de vista acional), implicando-lhe um comportamento. Assim, o interlocutor é solicitado, pelo ato de linguagem do locutor, a apresentar uma determinada reação: responder ou reagir (relação de influência).

No instante da enunciação, o locutor também atribui a si e ao interlocutor papéis linguageiros de dois tipos: a) o papel de controle, de força, do locutor sobre o interlocutor, que ocorre quando ele se autoconcede esse papel, impondo ao interlocutor um fazer/fazer ou um fazer/dizer. Neste caso, conforme Charaudeau (2008, p. 82), a "imposição do locutor sobre o interlocutor estabelece entre ambos uma relação de força."; b) o papel oposto, já que o locutor pode-se colocar numa posição de inferioridade em relação ao interlocutor, a partir do momento em que mostra ter necessidade do saber e do poder fazer do interlocutor. Neste caso, é produzida "uma solicitação do locutor ao interlocutor, o que estabelece entre ambos uma relação de petição.".

No comportamento elocutivo, o locutor enuncia sua posição em relação ao propósito referencial sem implicar, nessa tomada de posição, o interlocutor. Resulta, pois, uma enunciação cujo efeito é a modalização subjetiva da verdade do propósito enunciado, revelando o ponto de vista interno do locutor. Conforme Charaudeau, tal ponto de vista pode ser especificado da seguinte forma:

- Ponto de vista do modo de saber, que especifica de que maneira o locutor tem conhecimento de um Propósito. Corresponde às modalidades de 'Constatação' e de 'Saber/Ignorância'.

- Ponto de vista de avaliação, que especifica de que maneira o sujeito julga o Propósito enunciado. Corresponde às modalidades de 'Opinião' e de 'Apreciação'.

- Ponto de vista de motivação, que especifica a razão pela qual o sujeito é levado a realizar o conteúdo do Propósito referencial. Corresponde às modalidades de 'Obrigação', 'Possibilidade' e 'Querer'.

- Ponto de vista de engajamento, que especifica o grau de adesão ao Propósito. Corresponde às modalidades de 'Promessa', 'Aceitação/Recusa', 'Acordo/Desacordo', 'Declaração'.

- Ponto de vista de decisão, que especifica tanto o estatuto do locutor quanto o tipo de decisão que o ato de enunciação realiza. Corresponde à modalidade de 'Proclamação'. (Charaudeau, 2008, p. 83). 
No comportamento delocutivo, o locutor se apaga do ato de enunciação e também não implica o interlocutor. Ele mostra a maneira pela qual os discursos do mundo (o outro, o terceiro) a ele se impõem. Daí resulta uma enunciação com aparência de objetividade (no sentido de desligada da subjetividade do locutor) que deixa aparecer no palco do ato de comunicação ditos e textos não pertencentes ao locutor. Conforme Charaudeau, há, neste caso, duas possibilidades:

- O Propósito se impõe por si só. O locutor diz 'como o mundo existe' relacionando-o a seu modo e grau de asserção. É o caso das modalidades de 'Evidência', 'Probabilidade', etc.

- O Propósito é um texto já produzido por outro locutor, e o sujeito falante atuaria apenas como um relator (que, como sabemos, pode ser mais ou menos objetivo). Ele relata 'o que o outro diz e como o outro diz'. É o caso das diferentes formas do 'Discurso relatado'. (Charaudeau, 2008, p. 83).

Como podemos observar, a enunciação constitui um fenômeno complexo que evidencia a maneira como o locutor se apropria da linguagem e, assim, é levado a situar-se em relação ao seu interlocutor, ao que ele mesmo diz e ao mundo que o cerca.

Na compreensão do modo enunciativo do discurso, não podemos confundi-lo com a modalização que constitui apenas uma parte deste fenômeno complexo: a enunciação. A modalização torna explícitas, por meio de categorias de língua, as posições do locutor nas três relações que ele estabelece: com o interlocutor, com o dito e com o mundo que o cerca. Para cada comportamento enunciativo e suas respectivas especificações, há determinadas categorias modais. São modalidades do ato alocutivo: interpelação, injunção, autorização, aviso, julgamento, sugestão, proposta, interrogação, petição. Constituem modalidades do ato elocutivo: constatação, saber/ignorância, opinião, apreciação, obrigação, possibilidade, querer, promessa, aceitação/recusa, acordo/desacordo, declaração, proclamação. Por fim, são modalidades do ato delocutivo: asserção e discurso relatado. Tais categorias modais serão exemplificadas na análise da amostra desta pesquisa. 


\section{Metodologia}

Esta pesquisa apresenta-se como uma investigação qualitativa, em que os dados gerados ${ }^{2}$ serão analisados interpretativamente pela pesquisadora. Como bem aponta Cavalcanti (1989, p. 160), já houve "uma tendência para não considerar dados analisados qualitativamente como científicos ou para considerá-los como um meio para o fim de montar um experimento controlado para produzir dados quantificáveis.". Todavia, nos últimos anos, esse quadro se configura de modo diferente: os estudos quantitativos abrem espaço para a pesquisa qualitativa que, além de possibilitar a atuação participante do pesquisador ${ }^{3}$, também introduz novas metodologias na coleta de dados e nas formas de análise.

Assim, estamos adequando nossa pesquisa aos padrões do novo paradigma que enfatiza o processo de leitura e de escrita em detrimento da prática tradicional que priorizava o produto. Nesse processo, a leitura e a escrita de textos são compreendidas como atividades de linguagem, como práticas sociais inter-relacionadas e, sobretudo, como construção colaborativa, em que o olhar do outro está implicado.

Este trabalho apresenta os resultados da pesquisa feita com participantes de um curso de formação inicial docente, oferecido pela Secretaria de Ensino a Distância (SEAD), da Universidade Federal do Espírito Santo, instituição à que nos vinculamos desde junho de 2010, como professora do Departamento de Línguas e Letras e do Programa de Pós-Graduação em Linguística. Em especial, acompanhamos o Curso de

2 Os dados da amostra dizem respeito às situações de interação em ambiente virtual de aprendizagem (AVA) e foram extraídos da plataforma Moodle da Universidade Federal do Espírito Santo, para análise qualitativa.

3 Spradley (1980) afirma que o pesquisador se envolve com o objeto de investigação, pois ele participa e interfere, de forma relativa, na coleta de dados e na análise. A nosso ver, a intervenção participante do pesquisador, que transcende a simples observação e coleta de dados para o trabalho específico da pesquisa e se transforma em colaborador, constitui uma contribuição para o processo educacional, já que pretende modificar, de forma positiva, a realidade. Mas, ao mesmo tempo em que o pesquisador se mostra inserido na situação investigada, também deve manter certo distanciamento crítico necessário para descrever e analisar, de forma confiável, o fato observado. 
Graduação em Pedagogia, nas disciplinas Linguagem I e Linguagem II. ${ }^{4}$

Consideramos importante destacar que a Universidade Federal do Espírito Santo institucionalizou o Programa de Interiorização na Modalidade Aberta e a Distância - EaD e o desenvolve por meio da sua Secretaria de Educação Aberta e a Distância - SEAD, presente em 27 polos de apoio presencial da Universidade Aberta do Brasil (UAB) ${ }^{5}$, que estão localizados estrategicamente em cidades das mais diversas regiões do estado. Os cursos em desenvolvimento pela Ufes, na modalidade de $\mathrm{EaD}$, combinam as modalidades de ensino a distância e presencial, numa prática bimodal ou semipresencial.

A graduação em Pedagogia EaD da Ufes utiliza a plataforma Moodle em seu desenvolvimento. Os dados foram gerados, portanto, a partir das interações nesse ambiente virtual de aprendizagem (AVA), na medida em que os alunos-professores foram envolvidos em situações de prática de linguagem e responderam às propostas. A amostra é constituída por 21 postagens feitas pelos participantes do mesmo polo, no fórum de apresentação da disciplina Linguagem I, do curso de Pedagogia EaD. Dessas postagens, 4 serão analisadas a seguir. Portanto, esse ambiente virtual de aprendizagem, que nos forneceu amostra para análise, pode nos dizer muito sobre as práticas de letramento na formação inicial docente.

\section{Um olhar sobre a formação inicial docente em ambiente virtual de aprendizagem}

Como dissemos na seção anterior, nosso objetivo, aqui, é apresentar os resultados do acompanhamento do curso de Pedagogia, ofertado pela SEAD da Ufes na modalidade EaD. A escolha de tal curso deve-se à experiência já acumulada e também ao seu objetivo de formar professores das séries iniciais do ensino fundamental, o que tem grande pertinência em relação aos sujeitos focais da pesquisa mais ampla de pós-doutorado.

O curso de Pedagogia EaD da Ufes, até o momento, tem-se desenvolvido em três módulos, cada qual composto por seis disciplinas a serem cursadas pelos alunos. Escolhemos uma disciplina do terceiro

$4 \mathrm{O}$ projeto de pesquisa de pós-doutorado foi apresentado ao Comitê de Ética da Universidade Federal do Espírito Santo, tendo sido aprovado sob o número CAAE: 48307415.8.0000.5542.

5 Informações disponíveis no site da SEAD Ufes: < $\underline{\text { http://www.neaad.ufes.br/po- }}$ $\underline{\operatorname{los}>}$. Acesso em 20 dez. 2015. 
módulo: Linguagem I, também em função da pertinência em relação à metodologia de nossa pesquisa de pós-doutorado. A disciplina Linguagem I, em linhas gerais, trata do processo de alfabetização e do ensino da leitura e da escrita.

$\mathrm{Na}$ página de acesso ao aluno, essa disciplina organiza-se em sete semanas (semana 1 a semana 7) que decorreram nos meses de agosto e setembro de 2015. O aluno tem acesso a um mapa de atividades da disciplina, que apresenta, dispostos em uma tabela, o tema de cada semana, a informação de que aquele tema constitui ou não atividade avaliativa, o valor da atividade e as tarefas relacionadas ao aluno (em primeiro lugar), ao tutor presencial e ao tutor a distância.

Os tutores presenciais, conforme mostra o mapa de atividades, têm a função de dirimir dúvidas em relação ao conteúdo e também à dinâmica da disciplina esboçada no mapa de atividades, aprofundar as discussões, dar orientações sobre a atividade avaliativa, aplicar a avaliação presencial no polo; já o tutor a distância é responsável por incentivar os alunos nos fóruns promovendo a discussão e o posicionamento, dirimir dúvidas quanto aos capítulos sugeridos para leitura e também quanto à webconferência, realizar a avaliação da atividade proposta para o tema no ambiente virtual, segundo as orientações do professor. Como podemos ver, os tutores são sujeitos que, juntamente, com o professor e os alunos, protagonizam a dinâmica de ensino a distância na Universidade Federal do Espírito Santo e, nesse sentido, é importante que pesquisas também tenham em vista as ações desses sujeitos e suas implicações para o processo de ensino e aprendizagem.

Relativamente à dinâmica da disciplina Linguagem I, no decorrer das sete semanas, são propostas atividades de leitura e de reflexão sobre o texto lido. Em geral, os alunos precisam ler o texto, escrever de acordo com a proposta feita e postar o texto escrito na plataforma. É a reunião de cinco atividades escritas que comporá uma das notas da disciplina em questão, ou seja, 40 pontos. Os 60 pontos restantes destinam-se à avaliação presencial, composta por uma prova contendo questões de múltipla escolha e também uma questão dissertativa.

Além de o material disposto na plataforma apresentar embasamento teórico, as atividades têm em perspectiva uma reflexão pessoal do aluno acerca do tema em questão. A disciplina propõe dois fóruns: um de notícias e outro de apresentação, que decorre na primeira semana. É deste fórum (de apresentação) que extraímos os dados que compõem a amostra, 
uma vez que se trata de um gênero que potencializa a interação. Em linhas gerais, a proposta do fórum é que cada aluno se apresente e faça comentários sobre seu processo de alfabetização. Nas instruções, informa-se que o aluno poderá “citar o método de alfabetização, o material didático utilizado (cartilha ou livro de alfabetização), o modo como a sala de aula era organizada, a professora e etc.". (PLATAFORMA MOODLE SEAD/ UFES, 2015).

Passaremos, então, agora, à análise dos comportamentos enunciativos dos professores em formação no texto que eles postam no fórum de apresentação. Para uma melhor compreensão dos aspectos enunciativos, as postagens que constituem exemplos da nossa amostra serão transcritas tal como ocorrem no ambiente virtual de onde foram extraídas e, ao lado direito delas, serão identificadas as categorias modais.

\section{Fórum de apresentação}

por Aluna 1 - terça, 4 Ago 2015, 00:08

Olá! eu sou Aluna 1, do polo X.

INTERPELAÇÃO

Quando eu entrei na escola, já sabia ler e escrever, pois DECLARAÇÃO minha irmã mais velha me ensinou.

Por isso tenho recordações horríveis de minha primeira professora, pois ela não aceitava, acredito eu, que um aluno seu entrasse na escola alfabetizado.

Fui perseguida, maltratada e humilhada durante um bom tempo, até que mudou de professora que era o oposto da primeira.

Mesmo assim, me recordo que ela utilizava uma espécie de cartilha para ensinar os alunos a soletrar. Usava também uns carimbos para aprender as vogais. (asa, ema, imã, ovo e uva).

Naquela época, a única voz que ouvíamos durante a aula DECLARAÇÃO era a da professora. Fora isso, era silêncio absoluto.

Como podemos ver, a aluna inicia interpelando o interlocutor, demonstrando, assim, um comportamento alocutivo e esta será a única ocorrência neste sentido. A partir do momento em que começa a falar sobre seu processo de alfabetização, a aluna manifesta um comportamento predominantemente elocutivo: primeiro, por meio de declaração, afirma que 
a irmã foi a pessoa responsável por sua alfabetização, portanto, antes mesmo de entrar na escola, já sabia ler e escrever; em seguida, com base no pressuposto relativo às recordações do período escolar, vai avaliar o valor dessas recordações, julgando-as desfavoravelmente: de fato, quando diz que as recordações são horríveis e apresenta uma justificativa para isso, a aluna está falando de seu sentimento em relação ao propósito enunciado, por meio de uma apreciação.

Depois, novamente, declara, em tom de denúncia, que o tempo foi de perseguição, maus tratos e humilhação até a vinda de outra professora. Pela categoria do saber, a aluna apresenta os recursos que eram utilizados pela professora para a alfabetização da turma: a cartilha e os carimbos das vogais. E a seguir, mais uma vez, em tom de denúncia, a aluna declara que a voz dominante em sala de aula era a da professora e que aos alunos não era dada a palavra. Nesse sentido, percebemos, aqui, um enunciador que se manifesta contrariamente ao contexto de opressão por ele vivido no passado, constituindo-se, dessa maneira, a voz daquele que denuncia um tempo de silenciamento dos alunos no processo educacional.

\section{Re: Fórum de apresentação}

por Aluna 2 - terça, 4 Ago 2015, 09:46

Oi! Meu nome é Aluna 2!

Estou muito animada com a volta às aulas!

Acredito que todos se lembram de como foi ser alfabetizado, a alegria para muitos de começar a entender o que estava escrito nos vários lugares que encontrávamos.

Tive uma professora ótima, muito atenciosa e dedicada, apesar de termos que estudar com mais outra turma dois anos mais avançada do que a minha e ela ter que dar atenção a todos!

O material didático era o livro.

Nessa época, diferente da colega 1 ,

INTERPELAÇÃO

APRECIAÇÃO

OPINIÃO

APRECIAÇÃO

SABER

DISCURSO RELATA-

DO

os professores agiam de outra forma, dando espaço para os alunos falarem, comentarem sobre o que DECLARAÇÃO aprendiam e se estavam satisfeitos assim!

São boas lembranças...

APRECIAÇÃO 
Nesta segunda postagem, a aluna também começa a sua apresentação por meio de uma interpelação (Oi!), única ocorrência de comportamento alocutivo. Em seguida, já em comportamento elocutivo, faz uma apreciação favorável sobre a volta às aulas e, então, emite uma opinião relativamente à facilidade de se relatar as reminiscências do período de alfabetização, uma vez acreditando que, para todos, deve constituir uma "alegria" a aprendizagem da leitura e da escrita. Depois, faz uma apreciação favorável em relação à professora e toda a sua dedicação aos alunos e também uma apreciação desfavorável em relação à coexistência de duas turmas em uma mesma sala e, enfim, a presença de muitos alunos para dividir a atenção da professora.

E, para fazer a última declaração (a de que, em seu período escolar, os alunos tinham voz), a partir da qual a aluna manifesta uma apreciação (a de estar trazendo à baila boas lembranças), observamos que ela remete ao discurso da colega anterior, havendo aí um deslizamento para o discurso relatado, em um comportamento delocutivo: "Nessa época, diferente da colega 1...". Todavia, não há, aqui, o envolvimento do interlocutor, no sentido de retomar um comportamento alocutivo, o que também será observado nas postagens seguintes.

\section{Re: Fórum de apresentação}

por Aluna 3 - terça, 4 Ago 2015, 20:35

Oi! Sou Aluna 3, aluna do polo X

INTERPELAÇÃO

Fui matriculada na escola aos 5 anos de idade para fazer o DECLARAÇÃO pré I e depois o pré II.

Era muito divertido, com muitas brincadeiras de correr, APRECIAÇÃO pintar, desenhar e colagem. Tia X era muito carinhosa.

$\mathrm{Na} 1^{\mathrm{a}}$ série fui estudar em uma escola maior. Na alfabetização era utilizada uma cartilha que tinha todas as famílias DECLARAÇÃO das letras e atividades de pintar, ligar, marcar, etc.

$\mathrm{Na} 2^{\mathrm{a}}$ e $3^{\mathrm{a}}$ série usávamos livros que tinham umas histori- APRECIAÇÃO nhas que eu adorava ler.

Até hoje tenho todos esses livros e de vez em quando posso DECLARAÇÃO recordar lendo-os. 
Minha mãe sempre deu valor aos livros e por isso não se OPINIÃO desfez de nenhum enquanto eu era criança. Aprendi com ela o valor de um livro, a importância de seu conteúdo e que não podemos apenas jogar fora no lixo. Acho isso uma pena e um desperdício.

Sempre fui uma aluna tímida que só falava quando era DECLARAÇÃO apontada.

Por isso não me recordo muito bem se meus professores davam abertura para o aluno trocar ideias.

Acredito que isso não era muito valorizado.

DECLARAÇÃO

OPINIÃO

Da mesma forma que nas postagens anteriores, a aluna começa com uma interpelação. Mas, logo a seguir, já passa a um comportamento elocutivo, com apoio a categorias recorrentes nas mensagens anteriores: faz declarações acerca de sua primeira matrícula na escola, dos recursos utilizados para alfabetização (cartilha), dos livros utilizados, de sua timidez como aluna, da falta de abertura para manifestação dos alunos; também faz apreciação favorável em relação à professora (que era carinhosa), às historinhas que adorava ler; emite opinião acerca de se jogar um livro fora (manifesta-se contrariamente, dizendo ser uma pena e um desperdício) e também sobre o fato de não haver abertura aos alunos (aponta que não se valorizava muito isso).

Ainda que não haja uma interlocução direta entre os alunos, de modo a retomar o comportamento alocutivo, percebemos um dialogismo que se manifesta pelo recurso implícito à voz do outro: ou seja, quando a aluna fala de sua timidez, o que não a permitia participar das aulas, a menos que fosse solicitada, justifica, com isso, o fato de não se recordar de os professores, em seu período de escolarização, permitirem a participação dos alunos em sala de aula. Dessa maneira, a aluna está se reportando dialogicamente à experiência que as outras duas colegas já relataram: uma (Aluno 1) que, em tom de denúncia, traz a figura de um professor tradicional, austero; e a outra (Aluna 2) que ressalta a figura de um professor mediador de aprendizagem.

Nas postagens a seguir, podemos notar como os alunos insistem em retomar o discurso do outro, em uma prática dialógica diferenciada, no sentido de que não dialogam de forma direta, mas sim indiretamente: 


\section{Re: Fórum de apresentação}

por Aluna 4 - quarta, 5 Ago 2015, 13:39

Boa tarde!

INTERPELAÇÃO

Tenho algumas lembranças do período da minha alfabeti- APRECIAÇÃO zação pouco convencionais.

A sala era organizada em mesinhas com quatro cadeirinhas e ficávamos sempre em grupos ou a professora juntava todas as mesinhas fazendo uma só bem grande. Tinham muitos desenhos e tarefas que fazíamos pendurados entorno de toda a sala, como um varal.

Me recordo da atenção da professora para com todos, pois até hoje tenho muito carinho por ela.

Lembro do nome, do rosto e da forma como me tratava. Muitas tarefas eram parecidas com as que meus colegas já mencionaram

mas eu gostava muito de utilizar a cartilha para escrever as letras que aprendia.

Eram utilizadas muitas histórias, desenhos, cartilhas e li- SABER vros também.

E ainda lembro do cheiro da minha lancheira. Época muito boa para recordar!

\section{SABER}

APRECIAÇÃO

DISCURSO RELATADO

DECLARAÇÃO

APRECIAÇÃO

\section{Alfabetização}

por Aluna 5 - sábado, 8 Ago 2015, 11:02

Bom dia. Meu nome é Aluna 5 e sou aluna do Polo X. INTERPELAÇÃO

Iniciei meu processo de escolarização muito cedo e tam- APRECIAÇÃO bém a alfabetização.

Infelizmente não me recordo dos métodos, materiais e APRECIAÇÃO professores.

Bom ler as experiências de cada um aqui citadas

DISCURSO RELA-

TADO

porém infelizmente não me recordo das minhas.

APRECIAÇÃO

É muito comum observar alunos com recordações "pouco convencionais" - como a lembrança do cheiro da lancheira - e também alunos que não têm muito o que contar e, neste caso, sempre há um tom de lamento por não poder compartilhar com os demais as reminiscências do 
período de alfabetização. Assim, percebemos uma recorrência das categorias de saber e de apreciação - ora favorável, ora desfavorável - marcando o comportamento elocutivo predominante. De fato, os alunos, de modo geral, na medida em que enunciam seus pontos de vista sobre o propósito referencial, não implicam uma tomada de posição de seu interlocutor.

Pela categoria do saber, a primeira aluna expõe o modo como a sala de aula era organizada, quais eram os recursos didáticos utilizados. Pela categoria da apreciação, a primeira aluna, avalia como "pouco convencionais" suas reminiscências de alfabetização, avalia a professora como "atenciosa", o período de alfabetização como uma "época muito boa para recordar"; e a segunda avalia a escolarização como um período que começou cedo para ela, e o fato de ela não se recordar "dos métodos, materiais e professores" como algo negativo.

Ainda que isso ocorra, como já observamos anteriormente, aqui também os alunos vão remeter ao discurso de outrem, passando, então, a um comportamento delocutivo: no primeiro caso, quando a aluna compara as tarefas que ela fez no período de alfabetização às tarefas a que os colegas se reportaram, faz isso por meio de um discurso narrativizado, em que o discurso de origem (dos colegas) integra o dizer do aluno que está com a palavra; no segundo caso, quando a aluna diz "Bom ler as experiências de cada um aqui citadas", faz uma asserção que diz respeito não exatamente à verdade do propósito (leitura das experiências de cada um), mas sim à enunciação, ligada ao modo de dizer, ou seja, ao fato de ser bom poder ler o que os outros escreveram.

\section{Considerações finais}

Os resultados desse trabalho de análise nos permitem reconhecer a posição dos sujeitos comunicantes no contrato estabelecido pelo fórum de apresentação, que foi utilizado na disciplina Linguagem I, do curso de graduação em Pedagogia EAD da Ufes, no qual esses sujeitos se matricularam. Assim, podemos observar a posição que o sujeito ocupa em relação ao interlocutor, em relação ao que ele mesmo diz e também em relação ao que o outro diz no fórum.

Neste contrato, observamos a predominância do comportamento elocutivo por parte do sujeito comunicante, com destaque para as categorias modais de declaração, apreciação, opinião, saber, que denotam um enunciador engajado, no sentido de que se compromete com o enunciado. Mas há também um deslizamento para o comportamento delocutivo, 
marcado pela categoria do discurso relatado, mediante a qual percebemos a imagem de um enunciador que reporta-se à voz de outro para com ela estabelecer um diálogo em consonância ou dissonância.

E é nessa medida que os alunos-professores do curso de Pedagogia $\mathrm{EaD}$ da Ufes produzem seu conhecimento: na interação com o objeto de ensino, quando, pela linguagem, escrevem sobre seu processo de alfabetização; e também na interação com os outros colegas, mesmo que indiretamente, quando, por meio de um comportamento elocutivo, trazem não apenas dados informativos sobre sua alfabetização, mas, sobretudo, quando manifestam seu ponto de vista sobre o vivido, de modo a projetar um novo olhar sobre o futuro.

\section{REFERÊNCIAS}

AMARAL, L. H., AMARAL, C. L. C. Tecnologias de comunicação aplicadas à educação. In: MARQUESI, S. C.; ELIAS, V. M. da S.; CABRAL, A. L. T. (Orgs.). Interações virtuais: perspectiva para o ensino da Língua Portuguesa a distância. São Carlos: Claraluz, 2008. pp. 11-20.

CAVALCANTI, M. do C. Interação leitor - texto: aspectos de interpretação pragmática. Campinas: Editora da UNICAMP, 1989.

CHARAUDEAU, P. Uma teoria dos sujeitos da linguagem. In: MARI, H.; MACHADO, I. L.; MELLO, R. de (Orgs.). Análise do Discurso: fundamentos e práticas. Belo Horizonte: NAD/FALE/UFMG, 2001.

. Uma análise semiolingüística do texto e do discurso. In: PAULIUKO-

NIS, M. A. L.; GAVAZZI, S. (Orgs.). Da língua ao discurso: reflexões para o ensino. Rio de Janeiro: Lucerna, 2005.

. Linguagem e discurso: modos de organização. São Paulo: Contexto, 2008.

RANGEL, E. Livro Didático de Língua Portuguesa: o retorno do recalcado. In.: DIONISIO, A. de P.; BEZERRA, M. A. O Livro Didático de Português: múltiplos olhares. Rio de Janeiro: Lucerna, 2005.

SPRADLEY, J. Participant observation. Nova York: Holt, Renehart e Winston, 1980.

Recebido em: 13/12/2018

Aceito em: 27/06/2019 